\title{
Postoperative supplementation of propionate and silicon dioxide in patients after total gastrectomy - preliminary report
}

\author{
Dorota Domagalska ${ }^{1}$, Bartosz Grzechulski ${ }^{1}$, Jacek Paszkowski ${ }^{1}$, Mirosława Gałęcka ${ }^{2}$, Tomasz Banasiewicz ${ }^{1}$ \\ ${ }^{1}$ Department of General, Endocrine Surgery and Gastroenterological Oncology, Poznan University of Medical Science, Poznan, \\ Poland \\ ${ }^{2}$ Institute of Microecology, Poznan, Poland
}

Gastroenterology Rev 2020; 15 (3): 253-257

DOI: https://doi.org/10.5114/pg.2020.99040

Key words: gastrectomy, silicon dioxide, propionate, diarrhea, surgery.

Address for correspondence: Dorota Domagalska MD, Department of General, Endocrine Surgery and Gastroenterological Oncology, Poznan University of Medical Science, 49 Przybyszewskiego St, 60-355 Poznan, Poland, phone: +48 618691122, e-mail: dorotablazejewska@gmail.com

\begin{abstract}
Introduction: Post-operative impairment of gastrointestinal tract function and metabolic consequences occur in patients after gastrectomy by Roux-en-Y method. Short-chain fatty acids and silicon dioxide may prove beneficial in the treatment of these conditions.

Aim: To evaluate a preparation containing propionic acid and silicon dioxide on the body weight, number of stools and their consistency (the Bristol scale), and pain and a feeling of gastric fullness after a meal, in patients after gastrectomy by Roux-en-Y method.

Material and methods: Measurements were performed at the beginning of the study, on day 7 and 14 of application (Colostop ${ }^{\oplus}$; Miralex, 2 × $15 \mathrm{~g} /$ day).

Results and conclusions: Initially the average daily number of movements was 10/day, after the therapy it was 3.8/day. At the beginning of the study, 3 patients described their faeces as type 6 and two as type 7 on the Bristol scale. After supplementation, 3 patients described stool consistency as type 5, and two as type 4. Initially, patients rated their pain at 3.4/10 on average, the stomach fullness as 4.6/10. At the end of the study, 3 patients did not feel any pain, while others reported pain at 1/10. Four patients described their feeling of gastric fullness as $1 / 10$, and 1 no longer observed this feeling. Patients disclaimed any adverse effects, and satisfaction after therapy reached 9-10/10 points. Patients' body weight did not change significantly. An improvement in standard diet tolerance was observed. Despite the limited study group, clinical benefits of the supplementation were observed.
\end{abstract}

\section{Introduction}

The digestion process in patients who have undergone total gastrectomy with Roux-en-Y method due to cancer is altered irreversibly. Changes within the physiology of the digestive system are not only related to the acceleration of the intestinal passage, enzyme secretion, and hormonal aberrations, but also with breaking down food and the capacitive function [1]. Additionally, the cancer itself supports undernourishment and cachexia. They can be determined as mechanical-metabolic aberrations.

Roux-en-Y gastric resection, which is one of the most frequently performed operations in cancer pa- tients, limits the duodenal passage that regulates the exocrine pancreatic function, including the insulin production and secretion. What is more, it also influences the secretion of hormones regulating the activity of the digestive tract, such as somatostatin and cholecystokinin $[2,3]$.

Due to the above, patients may suffer from a series of metabolic consequences following the surgery. These aftermaths include dumping syndrome, Roux loop syndrome, afferent loop syndrome, loss of the body mass, postgastrectomy bone disease, and anaemia [4].

Dumping syndrome reveals itself in the form of diarrhoea, nausea, and abdominal pain. The main reason underlying dumping syndrome is the limited capacity of 
the stomach. Partially digested, highly osmotic chyme passing into the small intestine stimulates the transportation of extracellular fluid into its lumen, which results in an excessive amount of fluid in the digestive tract and intensifies the occurrence of diarrhoea [5].

It has been documented that short-chain fatty acids (SCFA) along with silicon dioxide $\left(\mathrm{SiO}_{2}\right)$ are effective in treating diarrhoea and other intestinal conditions [6]. Short-chain fatty acids (acetate, propionate, butyrate) produced by bacteria present in the large intestine stand as the main energetic substrate for intestinal epithelial cells [7]. Butyric acid or propionic acid is used in treating and preventing various diseases or disorders within the digestive system, such as diarrhoea, intestinal inflammation, functional disorders, dysbiosis, and conditions following surgical procedures or chemotherapy $[8,9]$. Total concentration of the SCFA in the intestinal lumen ranges from 60 to $150 \mathrm{mmol} / \mathrm{kg}$, whereas the proportions for acetate, propionate, and butyrate are, respectively, $60: 22: 18$ [10].

Silicon dioxide creates a protective layer of the intestinal mucosa by connecting with its glycoproteins [11]. The above-mentioned activity supports the intestinal barrier, which removes harmful substances and improves the absorbing surface of the intestine. Along with short-chain fatty acids, it also supports promotion of the development of a positive bacterial flora. Silicon dioxide is known for its highly hygroscopic activity because it binds significant amounts of water. Silicon dioxide is a safe substance, and according to Directive No. 95/2/EC there are currently various allowed uses of silicon dioxide as an E551 anti-caking agent. The European Food Safety Authority stated in its opinion of 18 May 1990 that the acceptable daily intake (ADI) for this particular additive is "not specified" [12].

\section{Aim}

The aim of the preliminary test performed in the General, Endocrinological Surgery, and Gastroenterological Oncology Clinic at Heliodor Święcicki Clinical Hospital in Poznan was to evaluate the influence posed by the preparation containing propionate and silicon dioxide on the intestinal passage in patients operated with the Roux-en-Y method due to gastric cancer.

\section{Material and methods}

The evaluation included 5 patients who underwent this particular surgery. The examination covered recording the body mass before the procedure, after the procedure, as well as after 14 days of using the preparation. As well as the above, the examination focused on the number of bowel movements before the study, and after 7 and 14 days, the stool consistency according to the Bristol Stool Form Scale, along with observed pain ailments and the experience of epigastric fullness after a meal. Additionally, particular attention was paid to possible adverse reactions associated with consuming the preparation, and whether or not the patient accepted the preparation. The preparation was implemented into the patients' diet between the $7^{\text {th }}$ and $16^{\text {th }}$ day after the surgery.

Patients were using a preparation containing propionic acid and colloidal silicon dioxide (Colostop ${ }^{\circledR}$; Miralex, Poznan) in a standard dose administered in accordance with chronic recommendations, which is $15 \mathrm{~g}$ two times per day. A single dose (15 g) contained 500 $\mathrm{mg}$ of sodium propionate (385 $\mathrm{mg}$ of propionic acid) and $1000 \mathrm{mg}$ of colloidal silicon dioxide.

\section{Results}

Results of the conducted observations are shown in Table I. Due to an insufficient number of evaluated patients, the study did not include statistical analysis.

Body mass loss following the surgery, ranging from 2 to $5 \mathrm{~kg}$, was reported in 4 patients. One patient gained $1 \mathrm{~kg}$ of body mass. Initially, 4 out of the 5 patients followed a pulpy diet or well fragmented food, whereas only 1 patient determined his diet as normal.

The average number of bowel movements reached 10 per day (between six and 14 bowel movements per day). When evaluating the stool consistency according to the Bristol scale, 3 patients declared type 6 (mushy consistency with ragged edges), while 2 patients declared type 7 (liquid stool, with no solid pieces, liquid).

Patients evaluated pain ailments following a meal before they started consuming the preparation on a scale from 0 to 10 . The average evaluation was 3.4/10 (from 2/10 to 5/10). The feeling of epigastric fullness was assessed in a similar way, on a scale from 0 to 10 . The average assessment equalled 4.6/10 (from 3/10 to 6/10).

After 7 days of using the preparation the average number of bowel movements during a single day was 4.2 (three to five bowel movements per day). Two patients determined the stool consistency according to the Bristol scale as type 6 , while the remaining 3 patients determined it to be type 5 (soft blobs with clearcut edges). Pain ailments following a meal in these patients equalled 3.2/10 (from 3/10 to 4/10). The patients stated that the feeling of epigastric fullness equalled $3.6 / 10$, on a scale from 0 to 10 (from $3 / 10$ to $5 / 10$ ).

Fourteen days after the initial use of the preparation the average number of bowel movements in patients during a single day was 3.8 (three to four bowel movements per day). Three patients determined the stool consistency according to the Bristol scale as type 5, 
Table I. The evaluated clinical parameters in patients after total gastrectomy performed with the Roux-en-Y method due to gastric cancer

\begin{tabular}{|c|c|c|c|c|c|}
\hline Parameter & $\mathrm{F} ; 64$ & $M ; 57$ & M; 59 & $\mathrm{~F} ; 71$ & M; 68 \\
\hline $\begin{array}{l}\text { Status of the patient at the } \\
\text { beginning of the study }\end{array}$ & Hospital & Home & Hospital & Hospital & Home \\
\hline $\begin{array}{l}\text { Day of implementing the } \\
\text { supplementation (from the day } \\
\text { of gastric resection) }\end{array}$ & 7 & 16 & 8 & 9 & 12 \\
\hline Description of the followed diet & $\begin{array}{l}\text { Pulpy diet, the } \\
\text { so-called 'hospital' } \\
\text { diet }\end{array}$ & $\begin{array}{l}\text { The so-called } \\
\text { 'light' diet, with } \\
\text { a recommendation } \\
\text { to thoroughly } \\
\text { chew and wash } \\
\text { down the food, } \\
\text { with addition of } \\
1 \text { nutridrink a day }\end{array}$ & $\begin{array}{l}\text { Hospital diet, } \\
\text { pulps, blended } \\
\text { food, from time } \\
\text { to time with an } \\
\text { added supplement } \\
\text { (most probably } \\
\text { - Protifar) }\end{array}$ & $\begin{array}{l}\text { Hospital diet, } \\
\text { pulps, blended } \\
\text { food, from time } \\
\text { to time with an } \\
\text { added supplement } \\
\text { (most probably } \\
\text { - Protifar) }\end{array}$ & $\begin{array}{l}\text { 'Normal' diet, } \\
\text { home-based } \\
\text { food, with the } \\
\text { recommended } \\
2 \text { bottles of } \\
\text { nutridrink a day }\end{array}$ \\
\hline $\begin{array}{l}\text { Weight before the procedure } \\
{[\mathrm{kg}]}\end{array}$ & 86 & 64 & 59 & 61 & 68 \\
\hline $\begin{array}{l}\text { Weight after the procedure } \\
\text { (on the day of initiating the } \\
\text { Colostop supplementation) [kg] }\end{array}$ & 81 & 62 & 55 & 62 & 66 \\
\hline $\begin{array}{l}\text { Weight at the end of the } \\
\text { observation period (after } \\
14 \text { days) }[\mathrm{kg}]\end{array}$ & 83 & 64 & 56 & 61 & 66 \\
\hline $\begin{array}{l}\text { Number of bowel movements } \\
\text { before initiating the } \\
\text { supplementation }\end{array}$ & 6 & 12 & 8 & 10 & 14 \\
\hline $\begin{array}{l}\text { Number of bowel movements } \\
7 \text { days after initiating the } \\
\text { supplementation }\end{array}$ & 3 & 5 & 4 & 4 & 5 \\
\hline $\begin{array}{l}\text { Number of bowel movements } \\
14 \text { days after initiating the } \\
\text { supplementation }\end{array}$ & 3 & 4 & 4 & 4 & 4 \\
\hline $\begin{array}{l}\text { Stool consistency according to } \\
\text { the Bristol scale before initiating } \\
\text { the supplementation }\end{array}$ & 6 & 7 & 6 & 7 & 6 \\
\hline $\begin{array}{l}\text { Stool consistency according to } \\
\text { the Bristol scale } 7 \text { days after } \\
\text { initiating the supplementation }\end{array}$ & 5 & 6 & 5 & 5 & 6 \\
\hline $\begin{array}{l}\text { Stool consistency according to } \\
\text { the Bristol scale } 14 \text { days after } \\
\text { initiating the supplementation }\end{array}$ & 5 & 5 & 5 & 4 & 4 \\
\hline $\begin{array}{l}\text { Pain ailments after a meal } \\
\text { before initiating the } \\
\text { supplementation }(0-10)\end{array}$ & 5 & 4 & 5 & 2 & 3 \\
\hline $\begin{array}{l}\text { Pain ailments after a meal } \\
7 \text { days after initiating the } \\
\text { supplementation }(0-10)\end{array}$ & 3 & 3 & 4 & 3 & 3 \\
\hline $\begin{array}{l}\text { Pain ailments after a meal } \\
14 \text { days after initiating the } \\
\text { supplementation }(0-10)\end{array}$ & 0 & 0 & 1 & 0 & 1 \\
\hline $\begin{array}{l}\text { Epigastric fullness after } \\
\text { a meal before initiating the } \\
\text { supplementation }(0-10)\end{array}$ & 5 & 5 & 3 & 6 & 4 \\
\hline
\end{tabular}


Table I. Cont.

\begin{tabular}{|c|c|c|c|c|c|}
\hline Parameter & $F ; 64$ & M; 57 & M; 59 & $\mathrm{~F} ; 71$ & M; 68 \\
\hline $\begin{array}{l}\text { Epigastric fullness after a meal } \\
7 \text { days after initiating the } \\
\text { supplementation }(0-10)\end{array}$ & 3 & 3 & 3 & 5 & 4 \\
\hline $\begin{array}{l}\text { Epigastric fullness after a meal } \\
14 \text { days after initiating the } \\
\text { supplementation }(0-10)\end{array}$ & 1 & 1 & 1 & 0 & 1 \\
\hline Adverse reactions & No & No & No & No & No \\
\hline $\begin{array}{l}\text { The patient's acceptance of the } \\
\text { preparation (0-10) }\end{array}$ & 9 & 10 & 10 & 9 & 10 \\
\hline $\begin{array}{l}\text { Status of the patient at the end } \\
\text { of the study }\end{array}$ & Home & Home & Home & Home & Home \\
\hline $\begin{array}{l}\text { Description of the diet followed } \\
\text { after } 14 \text { days }\end{array}$ & $\begin{array}{l}\text { Home-based } \\
\text { diet, thoroughly } \\
\text { chewed, with the } \\
\text { addition of two } \\
\text { bags of Nutramil }\end{array}$ & $\begin{array}{c}\text { Home-based } \\
\text { diet, without } \\
\text { any significant } \\
\text { limitations, small } \\
\text { meals, frequent } \\
\text { meals, lot of } \\
\text { poultry meat, fish }\end{array}$ & $\begin{array}{l}\text { Three home- } \\
\text { based meals } \\
\text { per day (light } \\
\text { products, rich in } \\
\text { protein, eggs, fish, } \\
\text { yoghurts, cheese } \\
\text { and } 3 \text { portions } \\
\text { of Immuvene per } \\
\text { day, alternately }\end{array}$ & $\begin{array}{c}\text { Home-based } \\
\text { diet, without } \\
\text { any significant } \\
\text { limitations, small } \\
\text { meals, frequent } \\
\text { meals, lot of } \\
\text { poultry meat, fish }\end{array}$ & $\begin{array}{l}\text { Home-based diet, } \\
\text { blended, } 9 \text { times } \\
\text { a day, including } \\
\text { Impact } 1 \text { per day }\end{array}$ \\
\hline
\end{tabular}

whereas 2 patients determined it to be type 4 (smooth, like a soft sausage or snake). Three out of the 5 patients reported no pain ailments after meals (0/10), and 2 patients evaluated that the pain ailments following meals reached $1 / 10$. Four patients experience the feeling of epigastric fullness, the level of this sensation was determined as $1 / 10$. One patient no longer reported experiencing this type of ailments.

None of the patients reported any adverse reactions, and all patients fully accepted using the preparation, stating that their satisfaction equalled $9-10 / 10$ points (the average value was 9.6/10). After the study, the body mass of most patients slightly increased (by 1$2 \mathrm{~kg}$ ) or remained the same. The diet of these patients also changed. All patients followed a modified homebased diet, and 3 patients used widely available dietary supplements.

\section{Discussion}

Diarrhoea and other digestive tract ailments observed in patients after gastrectomy related with oncological reasons is always a considerable problem [13]. Recovery in these patients is difficult, and their energy expenditure related with maintaining the homeostasis is definitely greater than in the case of healthy people. Administering a preparation containing propionic acid from the group of short-chain fatty acids, as well as silicon dioxide, to such patients under observation gives some positive results. The preparation allows us to obtain a denser stool, and it simultaneously provides a trophic activity because it nourishes the intestinal mucosa and stimulates its regeneration.

By stimulating the development of the saprophytic flora, propionate also inhibits the development of pathogens, such as Escherichia coli, Campylobacter, or Salmonella, which also compete for their place of colonisation [14]. Because propionic acid supports the function related with the intestinal barrier integrity, measured as the increased transepithelial electrical resistance (TER), under a physical concentration ( $2 \mathrm{mM})$, it simultaneously has an influence on decreasing the intestinal permeability, which improves the function of the intestinal barrier. Moreover, it stimulates the biosynthesis of the mucous within the intestinal epithelium. It is worth noting that its presence within the intestinal lumen allows the proper $\mathrm{pH}$ to be maintained, and hence protects the digestive system against the invasion of microorganisms [15]. The above-mentioned modes of action seem to be particularly beneficial in conditions resulting from extended surgical resections performed within the scope of the digestive system, including gastric resections. On the one hand, these mechanisms of action stimulate the process of recovery and adaptation, and on the other hand they enable an accelerated clinical improvement by physiological decrease of adverse symptoms and metabolic outcomes. The combination of propionate and silicon dioxide is administered in acute travellers' diarrhoea, usually caused by toxins produced by bacteria or viruses [6]. A growing intestinal dysbiosis 
is quite characteristic for these conditions [16]. It is worth mentioning that patients suffering from diseases associated with chronic diarrhoeas can also benefit from using these substances. These conditions include inflammatory bowel disease (IBD), chronic pancreatitis, irritable bowel syndrome (IBS), and radiation-induced intestinal inflammation, not to mention a long-term chemotherapy or antibiotic therapy. In such conditions it is crucial not only to ensure densification of the intestinal content, but most of all to nourish the mucosal cell.

\section{Conclusions}

The study, despite a small sample group, indicates advantages resulting from using silicon dioxide and propionate in the form of one preparation in patients after gastric resection performed because of the existing neoplastic disease. Patients experienced considerable advantages from the digestive system. The presented preliminary study constitutes an element of prospective studies within the group of patients after extended resections performed within the digestive tract.

\section{Conflict of interest}

The authors declare no conflict of interest.

\section{References}

1. Mathias JR, Fernandez A, Sninsky CA, et al. Nausea, vomiting, and abdominal pain after Roux-en-Y anastomosis: motility of the jejunal limb. Gastroenterology 1985; 88: 101-7.

2. Yang YS, Chen LQ, Yan XX, et al. Preservation versus non-preservation of the duodenal passage following total gastrectomy: a systematic review. J Gastrointest Surg 2013; 17: 877-86.

3. Tomita R, Fujisaki S, Tanjoh K, et al. Studies on gastrointestinal hormone and jejunal interdigestive migrating motor complex in patients with or without early dumping syndrome after total gastrectomy with Roux-en-Y reconstruction for early gastric cancer. Am J Surg 2003; 185: 354-9.

4. Olesiński T. Pathophysiological consequences of total gastrectomy. Gastroenterol Klin 2015; 7: 90-5.

5. Van Beek AP, Emous M, Laville M, et al. Dumping syndrome after esophageal, gastric orbariatric surgery: pathophysiology, diagnosis, and management. Obesity Rev 2017; 18: 68-85.

6. Krokowicz L, Mackiewicz J, Wejman-Matela A, et al. Management of traveller's diarrhoea with a combination of sodium butyrate, organic acids and A-300 silicon dioxide. Gastroenterology Rev 2014; 9: 285-90.

7. Morrison DJ, Preston Y. Formation of short chain fatty acids by the gut microbiota and their impact on human metabolism. Gut Microbes 2016; 7: 189-200.

8. Sun M, Wu W, Liu Z, et al. Microbiota metabolite short chain fatty acids, GPCR, and inflammatory bowel diseases. J Gastroenterol 2017; 52: 1-8.

9. Banasiewicz T, Borycka-Kiciak K, Dobrowolska-Zachwieja A, et al. Clinical aspects of sodium butyrate application in dietary treatment of bowel diseases. Gastroenterology Rev 2010; 5: 329-34.

10. Topping D, Clifton P. Short-chain fatty acids and human colonic function: roles of resistant starch and nonstarch polysaccharides. Physiol Rev 2001; 81: 1031-164.

11. Guarino A, LoVecchio A, Pirozzi MR. Clinical role of diosmectite in the management of diarrhea. Expert Opin Drug Metab Toxicol 2009; 5: 433-40.

12. Rozporządzenie Komisji (UE) nr 1129/2011 z dnia 11 listopada 2011 r. zmieniające załącznik II do rozporządzenia Parlamentu Europejskiego i Rady (WE) nr 1333/2008 poprzez ustanowienie unijnego wykazu dodatków do żywności.

13. Davis JL, Ripley RT. Postgastrectomy syndromes and nutritional considerations following gastric surgery. Surg Clin North Am 2017; 97: 277-93.

14. Bird AR, Conlon MA, Christophersen CT, et al. Resistant starch, large bowel fermentation and a broader perspective of prebiotics and probiotics. Benef Microbes 2010; 1: 423-31.

15. Morrison DJ, Preston T. Formation of short chain fatty acids by the gut microbiota and their impact on human metabolism. Gut Microbes 2016; 7: 189-200.

16. Rodriquez C, Romero E, Garrido-Sanchez L, et al. Microbiota insights in Clostridium difficile infection and inflammatory bowel disease. Gut Microbes 2020; 12: 1725220.

Received: 11.05 .2020

Accepted: 19.05.2020 